\title{
PERANCANGAN USER INTERFACE HUMAN RESOURCE CLOUD MANAGEMENT SOFTWARE BERBASIS ANDROID
}

\author{
${ }^{1}$ Yudi Eko Windarto, ${ }^{2}$ Marfuah \\ ${ }^{1}$ Departemen Teknik Komputer, Fakultas Teknik, Universitas Diponegoro, \\ Jalan Prof Sudharto,SH, Tembalang, Kota Semarang, Jawa Tengah 50275 - Indonesia \\ ${ }^{2}$ Prodi Sistem Informasi, Fakultas Komputer, Universitas Universal, \\ Kompleks Maha Vihara Duta Maitreya, Sungai Panas, Batam 29456, Kepulauan Riau - Indonesia \\ Email: yudi@live.undip.ac.id, marfuah916@gmail.com
}

(Diterima: 19 Juli 2020, direvisi: 5 Agustus 2020, disetujui: 9 September 2020 )

\begin{abstract}
One social company that helps in the development of IT to help welfare organizations and companies such as building applications to develop IT and addressing social problems is the Tri-Niche Indonesia company. In addition to IT services the Tri-Niche also develops other innovative projects at home that support the resolution of various social problems through the power of IT by collaborating with welfare entities and companies. IT has unlimited potential, always advancing and developing. One of the things done by Tri-Niche Indonesia is by preparing an application to manage company employee data so that it is easier to make rescue related to human resources needed. The research objective was to build a user interface design for HR monitoring applications. First, make preparations in the form of identification of problems related to the user interface and data collection techniques using interview techniques. The design stage analyzes the solution and then builds a user interface based on user needs using HRCMS. HRCMS is a graphical display that is used as a liaison between the "HRCMS" Application and users. This research builds user interfaces to animate employee data using Android HRCMS. The results of this study consist of a simple User Interface design based on the principle of User Interface Design as a reference to make it easier for employees to use applications.
\end{abstract}

Keywords: android HRCMS, design, mobile application, user interface

\begin{abstract}
ABSTRAK
Salah satu perusahaan sosial yang berfokus pada pemanfaatan kekuatan teknologi informasi untuk membantu organisasi kesejahteraan dan perusahaan seperti membangun aplikasi inovatif untuk menyelesaikan kendala TI serta mengatasi masalah sosial adalah Tri-Niche Indonesia. Selain layanan TI Tri-Niche juga mengembangkan proyek inovatif in-house lainnya yang bertujuan untuk menyelesaikan berbagai masalah sosial melalui kekuatan TI dengan berkolaborasi dengan entitas kesejahteraan dan perusahaan. TI memiliki potensi yang tidak terbatas, selalu maju dan berkembang. Salah satu hal yang dilakukan Tri-Niche Indonesia ialah mempersiapakan aplikasi untuk memanajemen data pegawai perusahaan agar lebih mudah dalam melakukan pemantauan sumber daya manusia (SDM) yang dimiliki. Penelitian ini bertujuan membangun rancangan user interface terkait aplikasi pemantauan SDM. Pada tahap utama melakukan persiapan berupa identifikasi masalah yang berkaitan dengan user interface dan teknik pengumpulan data dengan melakukan wawancara. Tahap perancangan melakukan analisis solusi dan kemudian membangun user interface berdasarkan kebutuhan pengguna menggunakan HRCMS. HRCMS (Human Resource Cloud Management Software) merupakan bentuk tampilan grafis yang digunakan sebagai penghubung antara Aplikasi "HRCMS" dengan pengguna. Penelitian ini membangunan User interface untuk memantau data pegawai menggunakan Android HRCMS. Hasil penelitian berupa rancangan User Interface yang sederhana berdasarkan prinsip User Interface Design sebagai acuan untuk memudahkan para pegawai dalam penggunaan aplikasi.
\end{abstract}

Kata Kunci: android HRCMs, design, aplikasi mobile, user interface 


\section{PENDAHULUAN}

Teknologi Informasi memiliki potensi yang tidak terbatas, selalu maju dan berkembang. Perkembangan teknologi informasi yang begitu pesat juga harus diikuti dengan perkembangan perusahaan. Perusahaan yang ingin maju dan terus berkembang justru melihat perkembangan teknologi informasi yang begitu cepat sebagai peluang yang mendukung perkembangan perusahaan. Salah satu perusahaan yang selalu meningkatkan perkembangan perusahaan yaitu Tri-Niche Indonesia yang berada di Kota Semarang dengan tujuan untuk mengatasi masalah sosial yang lebih besar di masa depan.

Tri-Niche Indonesi merupakan salah satu perusahaan sosial yang berfokus pada pemanfaatan kekuatan teknologi informasi untuk membantu organisasi kesejahteraan dan perusahaan seperti membangun aplikasi inovatif untuk menyelesaikan kendala teknologi informasi serta mengatasi masalah sosial. Perusahaan Tri-Niche juga mengembangkan proyek inovatif in-house lainnya yang bertujuan untuk menyelesaikan berbagai masalah sosial melalui kekuatan teknologi informasi dengan berkolaborasi dengan entitas kesejahteraan dan perusahaan [1].

Salah satu hal yang dilakukan oleh Tri-Niche Indonesia ialah dengan mempersiapakan aplikasi untuk memanajemen data pegawai perusahaan agar lebih mudah dalam melakukan pemantauan terkait sumber daya manusia yang dimiliki. Adapun beberapa fitur yang terdapat dalam aplikasi data pegawai antara lain menampilkan menu login, daftar kehadiran pegawai, detail informasi gaji dan bonus. Persiapan aplikasi tersebut dalam desain aplikasi salah satu hal yang dilakukan yaitu membuat user interface yang sederhana berdasarkan prinsip, mengingat user interface memiliki peran yang sangat penting dalam efektifitas sistem informasi [2]. User Interface Design untuk memudahkan para pegawai dalam penggunaan aplikasi [3]. Dengan demikian tujuan penelitian ini yaitu membangun rancangan user interface terkait aplikasi pemantauan SDM. Pada tahap utama melakukan persiapan berupa identifikasi masalah yang berkaitan dengan user interface dan teknik pengumpulan data dengan melakukan wawancara terhadap 8 (delapan) orang pegawai Tri-Naiche Indonesia termasuk pimpinan dan manajer proyek. Tahap perancangan melakukan analisis solusi dan kemudian membangun user interface berdasarkan kebutuhan pengguna menggunakan HRCMS. HRCMS (Human Resource Cloud Management Software) merupakan bentuk tampilan grafis yang digunakan sebagai penghubung antara Aplikasi "HRCMS" dengan pengguna. Penelitian sebelumnya [4] mengenai kerangka kerja evaluasi User Interface (UI) dan User eXperience (UX) untuk lingkungan pembelajaran di bidang ilmu komputer dan pendidikan rekayasa perangkat lunak, penelitian ini menghasilkan 5 (lima) konsep dalam evaluasi UI/UX yaitu usability, utility, teknology, users and context.

Berdasarkan 5 konsep tersebut dijelaskan bahwa usability berkaitan dengan efektivitas, efisiensi, dan kepuasan pengguna terhadap suatu aplikasi. Utility mengenai kebergunaan objek atau aplikasi. Kemudian context dalam proses pengembangan aplikasi yang berkaitan dengan konsep, teknik dan pengujian. Users berkaitan dengan aktor atau class pengguna sistem sehingga menjadi penting untuk melibatkan mereka dalam proses evaluasi dan sekaligus menjadi sumber pengumpulan data untuk evaluasi. Kemudian juga perlu dipahami bahwa dalam proses evaluasi perlu memahami bagaimana peran technology yang digunakan, bagaimana pengguna belajar berinteraksi dengan teknologi, dan bagaimana teknologi dapat memfasilitasi kebutuhan pengguna. Karena proses evaluasi salah satunya mementingkan user maka pada tahap awal persiapan hingga pembangunan user interface juga dipandang pelu untuk keterlibatan user secara aktif.

\section{TINJAUAN PUSTAKA}

Penelitian terdahulu [5] mengenai UI/UX dengan metode google design mengatakan bahwa berdasarkan google analytics website adanya permasalahan yang terjadi diantaranya terkait faktor user interface yang tidak tepat dan menarik. Sehingga penelitian ini dilakukan untuk menghasilkan user interface yang memiliki keseragaman baik dari segi warna, font, hingga tata letak, user experience yang sesuai dengan pengalaman user.

Selanjutnya penelitian yang pernah ada mengenai analisis desain user interface dalam game edukasi [6]. Penelitian ini menempatkan objek peletakan elemen desain dengan pendekatan kualitatif. Dengan metode studi kasus hasil penelitian ini berupa kajian visual estetik terhadap desain user interface yang nantinya digunakan sebagai acuan dalam mendesain user interface game edukatif. 
User Interface merupakan bentuk tampilan grafis yang berhubungan langsung dengan pengguna [7][8]. User Interface berfungsi untuk menghubungkan antara pengguna dengan sistem operasi, sehingga komputer tersebut bisa digunakan [9][10]. User interface atau antarmuka pengguna merupakan tampilan berupa tulisan, gambar, petunjuk, dan tombol yang memungkinkan pengguna dapat berinteraksi dengan perangkat lunak tersebut [11][12][13]. Pembuatan antarmuka pengguna bertujuan untuk menjadikan media informasi menjadi mudah digunakan oleh pengguna, atau yang disebut dengan user friendly[14][15]. Istilah user friendly merujuk kepada kemampuan dimana suatu sistem mudah dioperasikan dan mempunyai sejumlah kemampuan lainnya sehingga pengguna merasa betah dalam mengoperasikan program tersebut [16][17].

Berdasarkan beberapa penelitian terdahulu [5] membangun user interface website yang berfokus pada device desktop menghasilkan bentuk branding dengan pemberian skema warna pada tampilan. Pemilihan flat design sebagai ilustrasi yang sesuai disetiap elemen dan juga konsistensi layout. Kemudian dalam penelitian [6] membangun user interface game edukatif berdasarkan elemen, ilustrasi, typografi, audio, dan tombol navigasi. Pada tiap elemen memiliki proporsi tampilan yang berbeda. Game edukasi berbasis komputer ukuran elemen navigasi antara 10-20\% dari ukuran layar, ukuran tampilan materi $60-70 \%$. Sedangkan game mobile Android untuk proporsi navigasi dibuat lebih besar yaitu $15-25 \%$ dari ukuran layar. Dengan demikian terdapat perbedaan yang harus diperhatikan dalam membangun user interface berbasis android, untuk menangani hal tersebut maka dalam penelitian ini membutuhkan tampilan grafis yang dapat menampilkan secara detail mengenai user interface yang dibangun yaitu dengan menggunakan HRCMS.

\section{METODE PENELITIAN}

Metode dalam penelitian ini berfokus pada 2 tahap awal yaitu tahap persiapan dan tahap perancangan. 2 tahapan ini menghasilkan rancangan user interface yang akan mempermudah dalam pembangunan sistem nantinya sebagaimana Gambar 1.

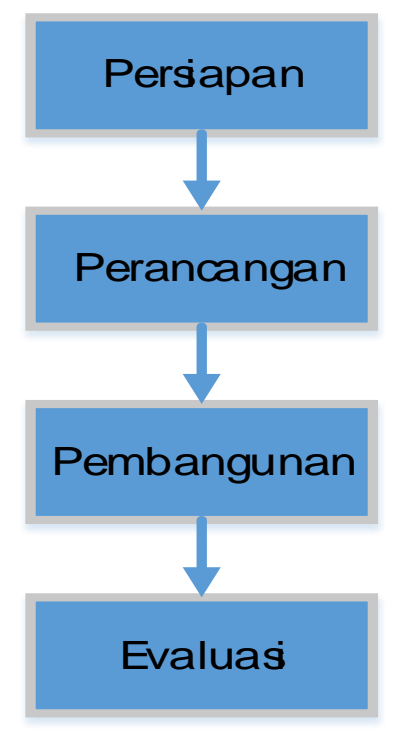

\section{Gambar 1. Prosedur Penelitian [18]}

Berdasaran Gambar 1 dapat dijelaskan bahwa pada tahap persiapan dilakukan identifikasi masalah yang berkaitan dengan user interface dan teknik pengumpulan data dengan melakukan wawancara terhadap 8 orang yang terdiri dari pimpinan, manajer proyek, HRD, marketing dan 4 orang programmer Tri-Niche Indonesia. Tahap perancangan dilakukan berdasarkan hasil yang didapatkan pada tahap persiapan yang kemudian dianalisis untuk memetakan rancangan solusi user interface yang akan dibangun. Kemudian pada tahap pembangunan yaitu melakukan pembangunan user interface berdasarkan kebutuhan pengguna yang user frendly menggunakan HRCMS. Tahap evaluasi dilakukan setelah pembangunan user interface maka tahap terakhir yaitu melakukan evaluasi 
ulang dengan demo user interface terhadap para pengguna aplikasi yaitu para pegawai Tri-Niche Indonesia.

\section{HASIL DAN PEMBAHASAN}

User interface aplikasi yang dirancanga berisi fitur diantaranya menampilkan menul login, daftar kehadiran pegawai, dan detail informasi gaji serta bonus. User interface aplikasi HRCMS menghasilkan bentuk visual secara umum stuktur desain user interface yang nantinya diharapkan menjadi acuan untuk menciptakan desain interface fungsional untuk menciptakan pengalaman pengguna yang baik. Halaman Login sebagaimana Gambar 2.

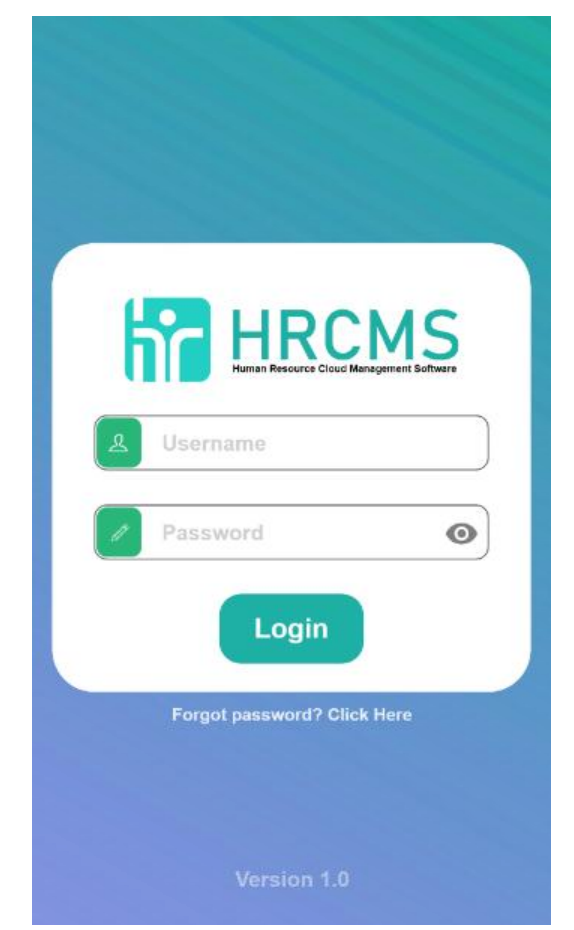

Gambar 2. Tampilan Halaman Login

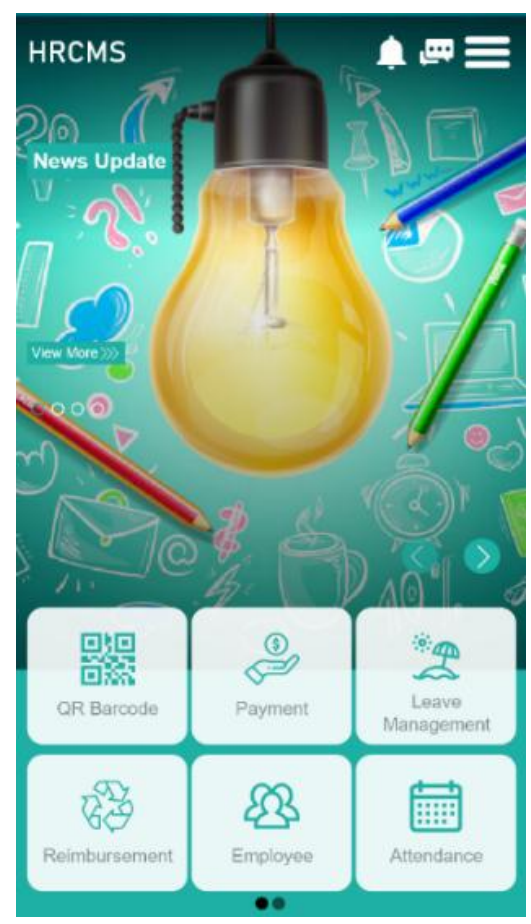

Gambar 3. Tampilan Halaman Utama

Gambar 2 merupakan halaman login. Pengguna memasukkan username dan password yang dimiliki. Apabila pengguna lupa terhadap username dan atau password maka dapat memanfaat kan fitur forget password. Gambar 3 menunjukkan tampilan halaman utama dimana user dapat melihat fitur-fitur apa saja yang tersedia dalam aplikasi. Halaman notification sebagaiaman Gambar 4. 


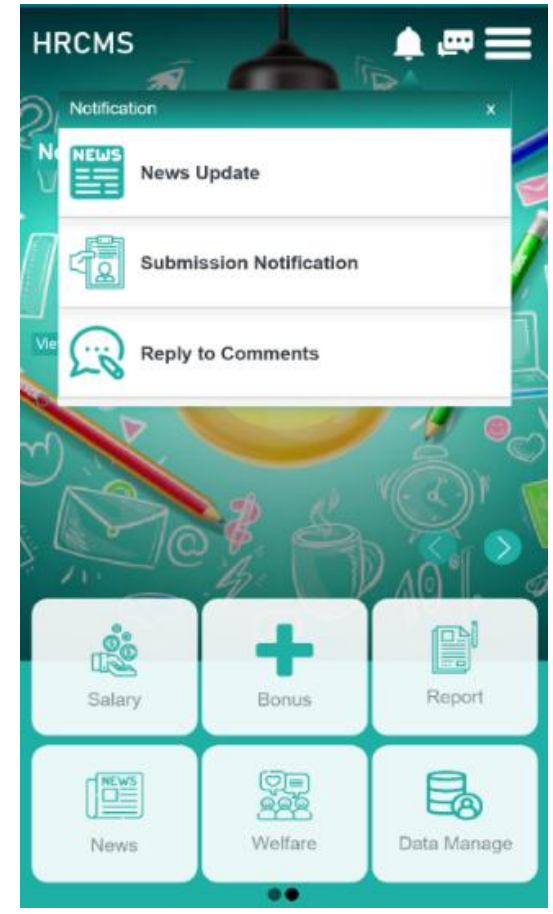

Gambar 4. Tampilan Halaman Notification

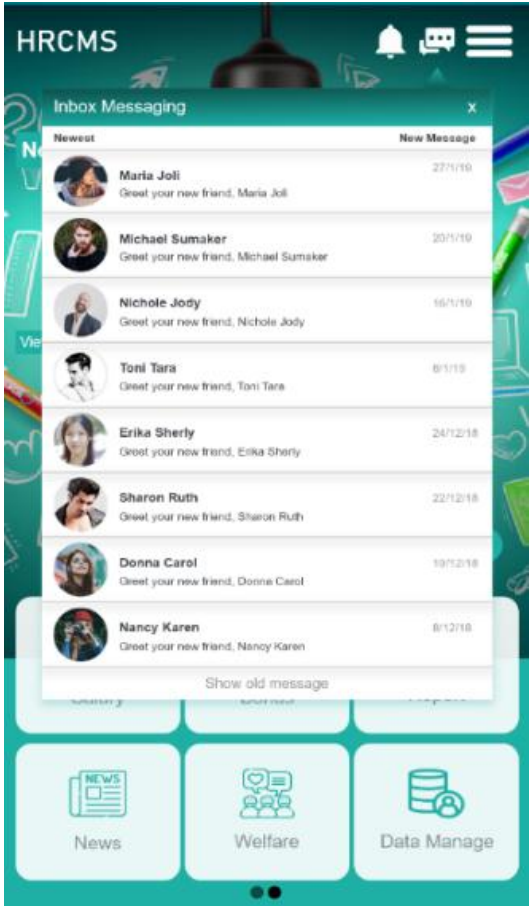

Gambar 5. Tampilan Halaman Inbox Messaging

Gambar 4 menunjukkan tampilan ketika user memilih fitur notification. Apabila user memilih fitur notification.maka akan muncul 3 pilihan, yaitu News Update, Submission Notification, dan Reply to Comments. Pada fitur News Update, pegawai akan menerima pemberitahuan mengenai berita yang baru saja dipublikasikan. Fitur Submission Notification, pegawai akan menerima pemberitahuan apakah pengajuan yang dilakukan di terima atau di tolak oleh perusahaan. Pada fitur Reply to Comments, pegawai akan menerima pemberitahuan dari user lain yang membalas komentar status. Halaman Inbox Messaging sebagaiamana Gambar 5 menunjukkan tampilan ketika user memilih fitur Inbox Messaging. Apabila user memilih fitur tersebut maka akan muncul daftar nama yang pernah mengirimkan pesan pribadi kepada pemilik akun tersebut. Halaman Obrolan sebagaimana Gambar 6.

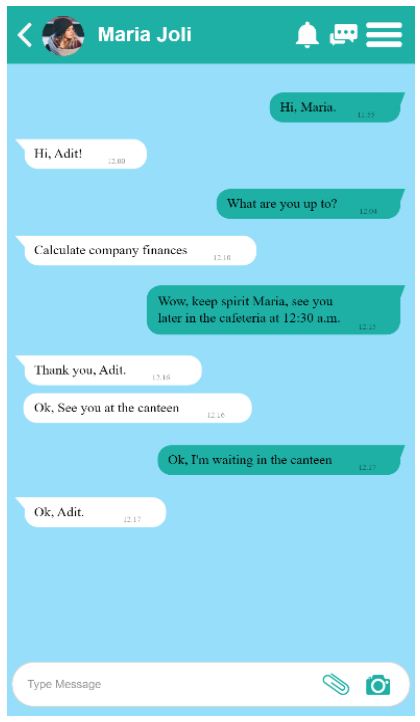

Gambar 6. Tampilan Halaman Obrolan

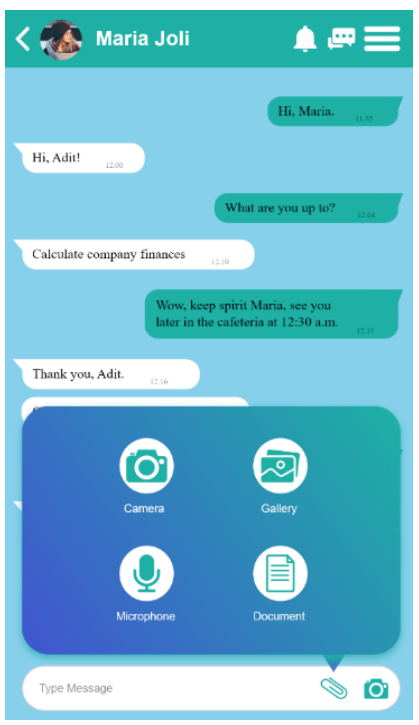

Gambar 7. Tampilan Saat User Memilih Fitur "Clip"

Gambar 6 menunjukkan tampilan ketika user memilih salah satu nama yang ada dalam Inbox Messaging. Apabila user memilih salah satu nama maka akan membuka halaman obrolan. Sedangkan pada Gambar 7 user akan mendapatkan fitur "Clip" digunakan untuk membuka lebih banyak lagi 
fitur yang disediakan yaitu, Camera digunakan untuk mengambil gambar atau video. Halaman Three Lines sebagaimana 8 .

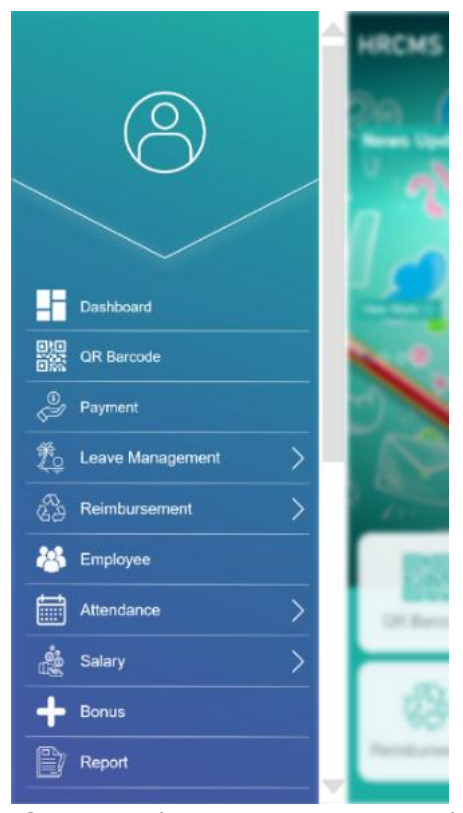

\section{Gambar 8. Tampilan Halaman Ketika User} Membuka Fitur Three Lines

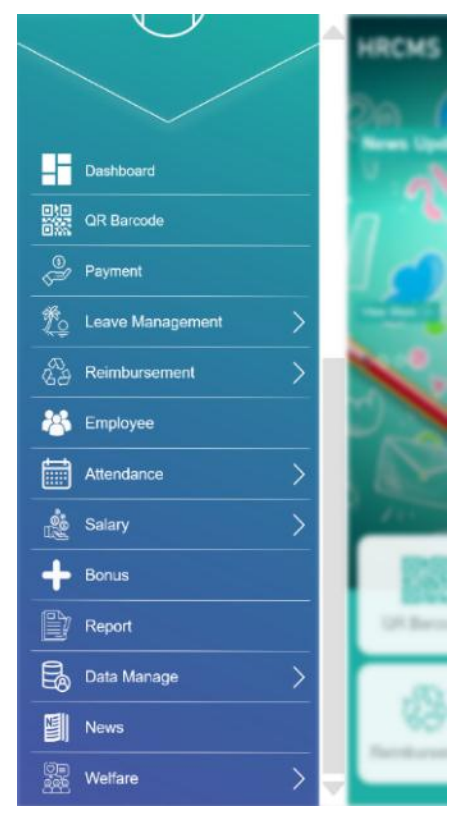

Gambar 9. Tampilan Halaman Three Lines Ketika Di Scroll Down

Gambar 8 menunjukkan tampilan ketika user memilih fitur Three Lines yang berada di bagian pojok kanan atas. Apabila user memilih fitur tersebut maka akan menggeser halaman utama dan menampilkan fitur - fitur yang berada di halaman utama dalam sudut pandang samping. Sedangkan Gambar 9 menunjukkan tampilan ketika user melakukan scroll down. Apabila user melakukan hal tersebut maka akan menampilkan fitur - fitur secara lengkap. Halaman $Q R$ Barcoden sebagaimana Gambar 10.

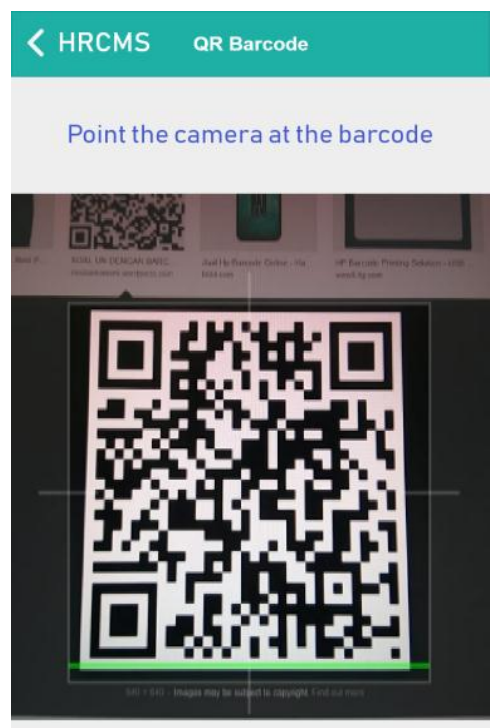

\section{Gambar 10. Tampilan Halaman $Q r$ Barcode}

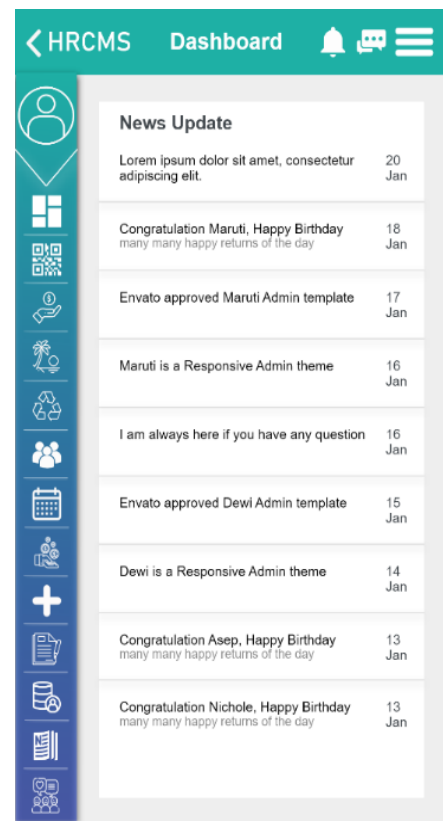

\section{Gambar 11. Tampilan Halaman News Update}

Gambar 10. menunjukkan tampilan ketika user memilih fitur $Q R$ Barcode. Apabila user memilih fitur tersebut maka akan secara otomatis mengaktifkan kamera smartphone. Fitur $Q R$ Barcode 
nantinya akan berguna untuk mengisi kehadiran pegawai. Gambar 11 menunjukkan tampilan ketika user memilih fitur News Update. Apabila user memilih fitur tersebut maka dapat melihat berita berita baru atau berita - berita yang terdahulu. Halaman Latest Posts sebagaiamana Gambar 12.

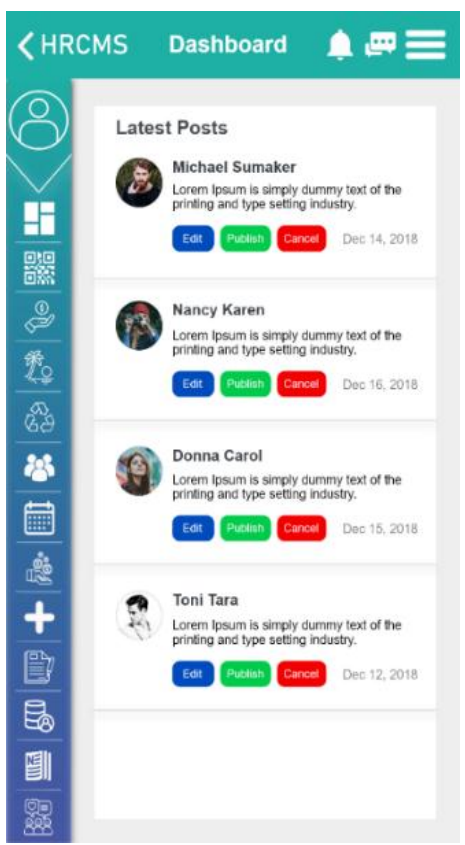

Gambar 12. Tampilan Halaman Latest Posts

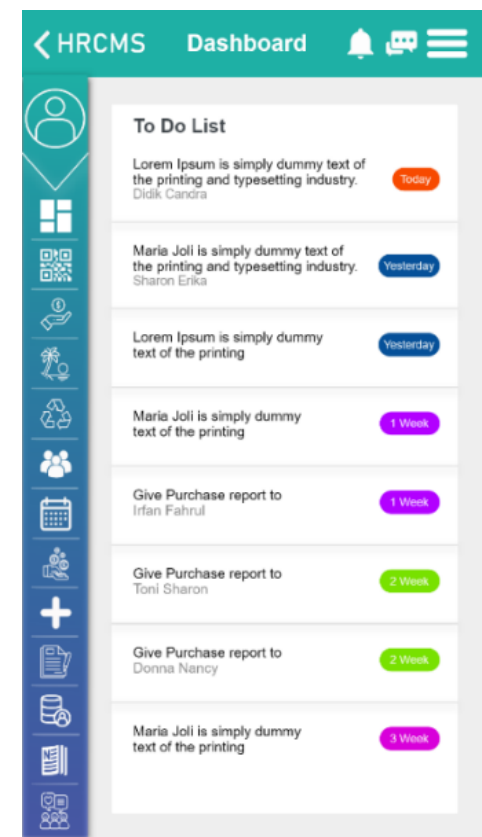

Gambar 13. Tampilan Halaman To Do List

Gambar 12 menunjukkan tampilan ketika user memilih fitur Latest Post. Apabila user memilih fitur tersebut maka dapat mengganti, memposting, dan membatalkan postingan terbaru atau postingan yang terdahulu. Gambar 13 menunjukkan tampilan ketika user memilih fitur To Do List. Apabila user memilih fitur tersebut maka dapat melihat daftar tugas - tugas pegawai yang telah dibuat dan harus dikerjakan pada suatu rentang waktu. Halaman Progress Box sebagaimana Gambar 14.

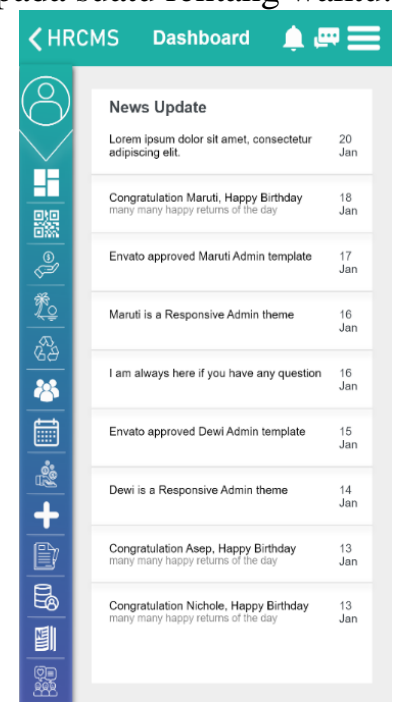

Gambar 14. Tampilan Halaman Progress Box

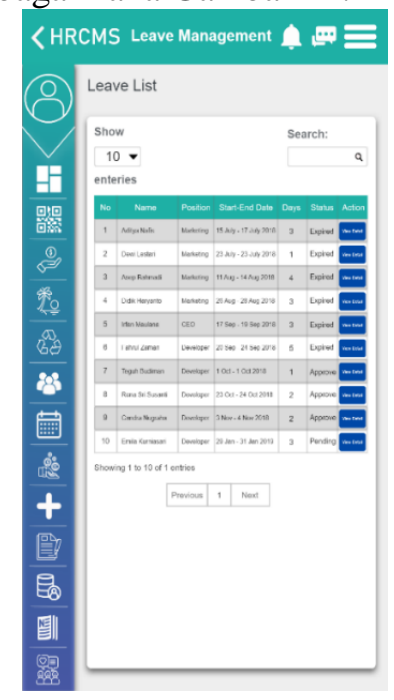

Gambar 15. Tampilan Halaman Leave Management "Leave List" 


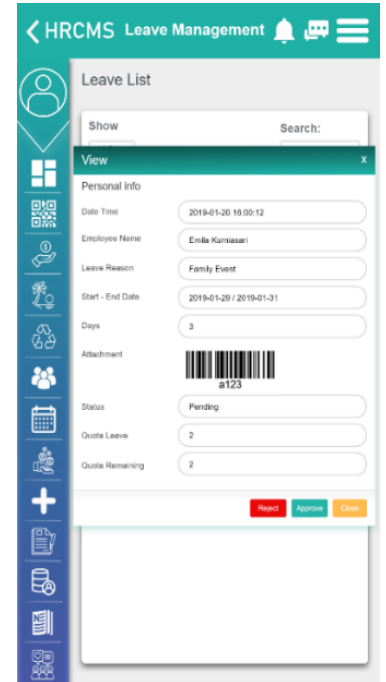

Gambar 16. Tampilan Halaman View Ketika Status Pending

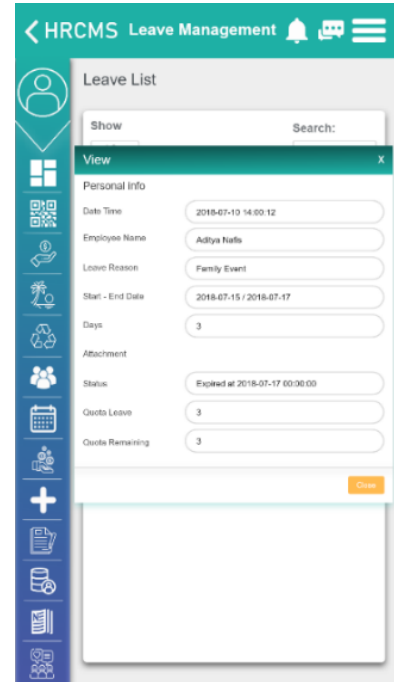

Gambar 17. Tampilan Halaman View Ketika Status Expired

Gambar 14 menunjukkan tampilan ketika user memilih fitur Progress Box. Apabila user memilih fitur tersebut maka dapat melihat kemajuan yang sudah dilakukan secara detail. Gambar 15 menunjukkan tampilan ketika user memilih fitur Leave Management bagian "Leave List".

Gambar 16 menunjukkan tampilan ketika user menekan View Detail pada bagian Action. Kemudian muncul halaman View. Pada halaman tersebut admin dapat melihat rincian lengkap permohonan cuti. Admin dapat memilih Reject sebagai menolak permohonan user, Approve sebagai menyetujui permohonan user, dan Cancel digunakan untuk menutup halaman view. Gambar 17 menunjukkan tampilan ketika user menekan View Detail pada bagian Action. Kemudian muncul halaman View. Apabila memilih nama yang sudah memiliki status Expired, maka hanya muncul detail permohonan yang sudah lama melakukan permohonan cuti dan telah disetujui oleh admin. Halaman Leave Management "Off List" sebagaimana Gambar 18.

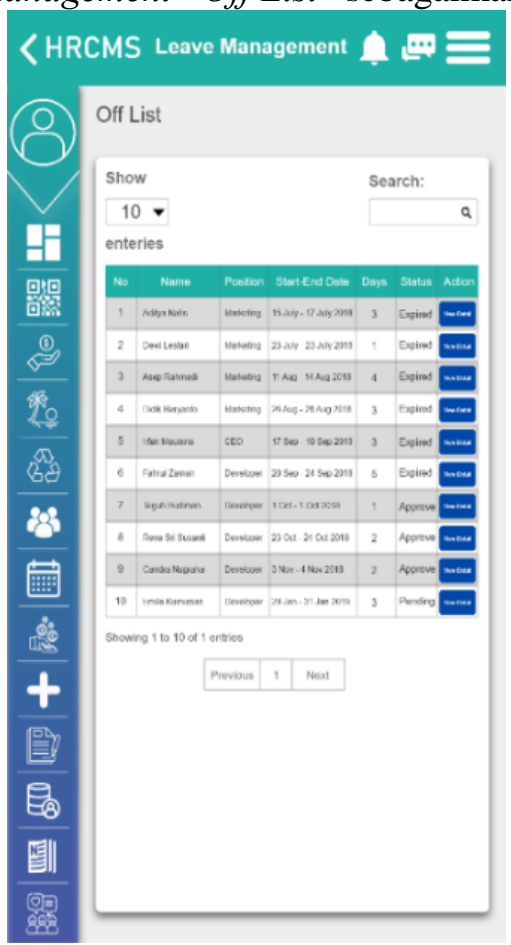

Gambar 18. Tampilan Halaman Leave Mangement "Off List"

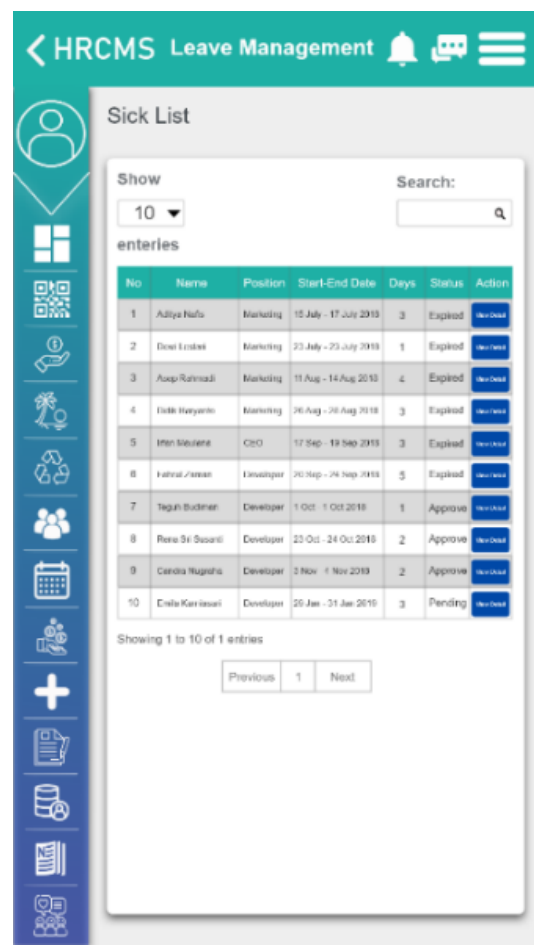

Gambar 19. Tampilan Halaman Leave Mangement "Sick List" 
Gambar 18 menunjukkan tampilan ketika user memilih fitur Leave Management bagian "Off List". Apabila user memilih fitur tersebut maka dapat melihat daftar - daftar nama yang sudah tidak aktif bekerja. Gambar 19 menunjukkan tampilan ketika user memilih fitur Leave Management bagian "Sick List". Fitur tersebut untuk melihat daftar - daftar nama yang melakukan permohonan izin sakit. Halaman Reimbursement "Claim List" sebagaiamana Gambar 20.

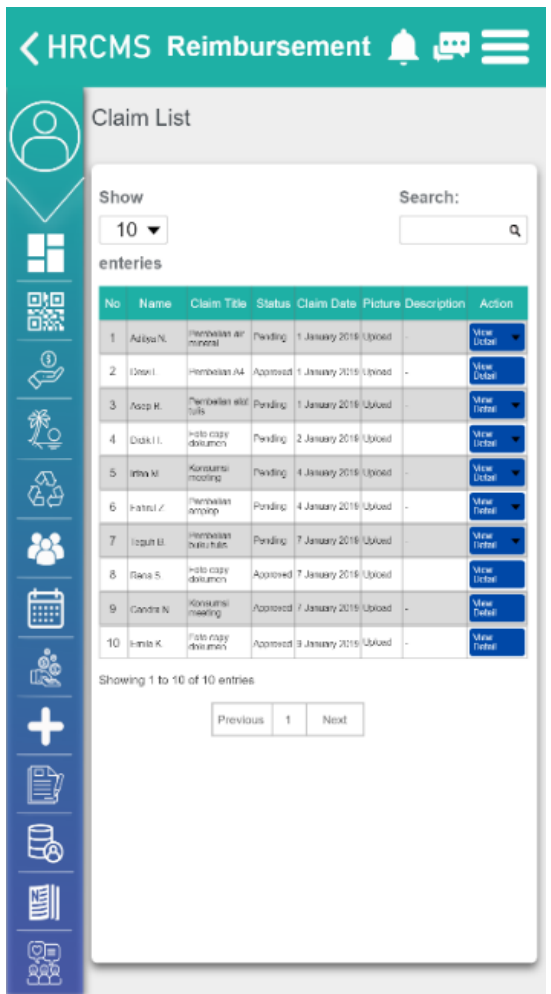

Gambar 20. Tampilan Halaman Reimbursement "Claim List"

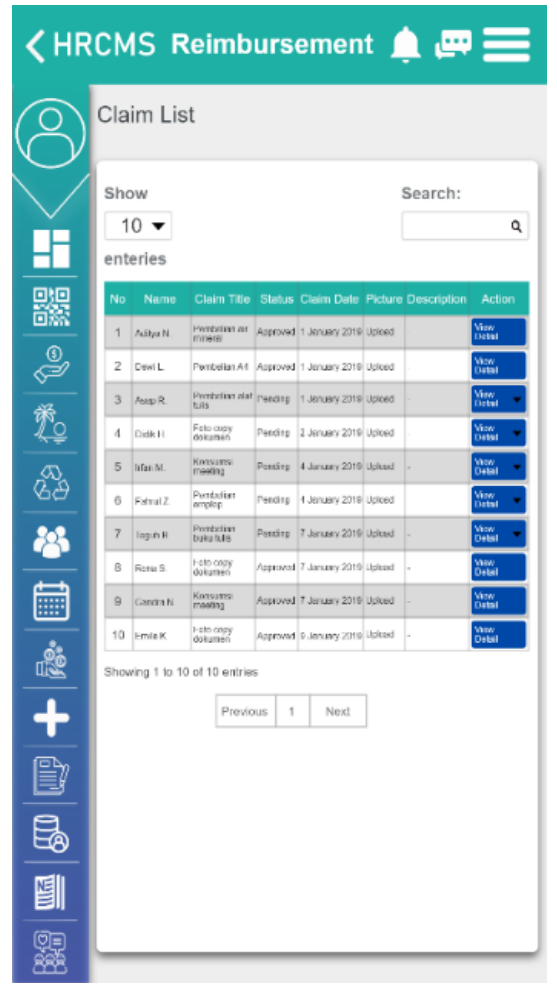

Gambar 22. Tampilan Saat Admin Telah Melakukan Approve

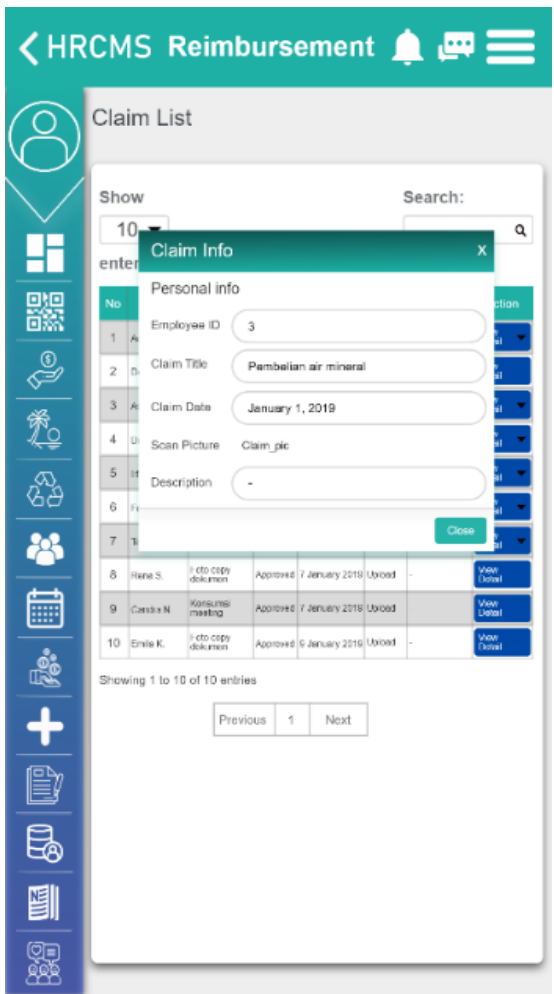

\section{Gambar 21. Tampilan Halaman Claim Info} Ketika Memilih View Detail

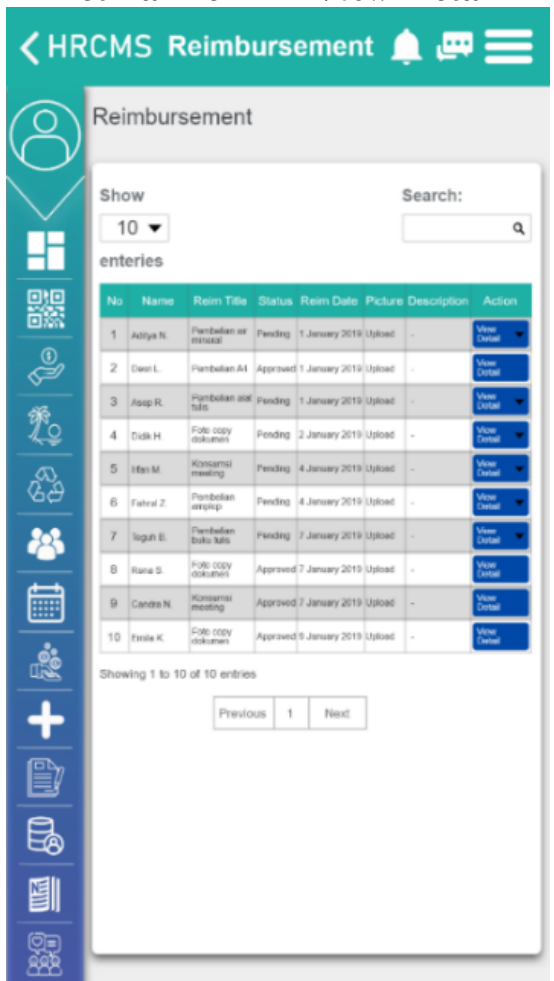

Gambar 23. Tampilan Halaman Reimbursement "Reimbursement List" 
Gambar 20 menunjukkan tampilan ketika user memilih fitur Reimbursement bagian "Claim List". Apabila user memilih fitur tersebut maka dapat melihat daftar - daftar nama pegawai yang ingin melakukan permohonan klaim untuk membeli alat - alat kantor maupun barang lainnya. Admin dapat melihat nama pegawai yang melakukan permohonan "Name". Claim Title digunakan sebagai keterangan barang yang ingin di klaim atau dibeli. Status digunakan apabila permohonan pegawai tersebut sudah di setujui atau belum di setujui oleh admin. Approve digunakan sebagai status apabila permohonan pegawai tersebut sudah disetujui oleh admin, dan Pending digunakan sebagai status apabila pegawai tersebut belum disetujui oleh admin, Claim Date digunakan sebagai waktu pegawai melakukan permohonan klaim barang. Picture digunakan untuk gambaran apa yang ingin di klaim oleh pegawai tersebut. Description digunakan sebagai keterangan detail barang yang ingin di klaim, dan Action digunakan admin untuk melihat lebih detail informasi permohonan klaim dan menyetujui permohonan.

Gambar 21 menunjukkan tampilan ketika admin memilih fitur View Detail. Apabila admin memilih fitur tersebut maka akan muncul detail informasi permohonan klaim yang diajukan oleh pegawai. Gambar 22 menunjukkan tampilan ketika admin melakukan Approve maka Status akan berubah menjadi Approved.

Sedangkan Gambar 23 menunjukkan tampilan ketika user memilih fitur Reimbursement bagian "Reimbursement List". Apabila user memilih fitur tersebut maka dapat melihat daftar - daftar nama pegawai yang ingin melakukan permohonan penggantian biaya. Admin dapat melihat nama pegawai yang melakukan permohonan "Name". Reim Title digunakan sebagai keterangan barang yang ingin biayanya akan diganti. Status digunakan apabila permohonan pegawai tersebut sudah di setujui atau belum di setujui oleh admin. Approve digunakan sebagai status apabila permohonan pegawai tersebut sudah disetujui oleh admin, dan Pending digunakan sebagai status apabila pegawai tersebut belum disetuju oleh admin. Reim Date digunakan sebagai waktu pegawai melakukan permohonan penggantian biaya. Picture digunakan untuk gambaran apa yang ingin biayanya akan diganti oleh pegawai tersebut. Description digunakan sebagai keterangan detail barang yang ingin di ganti biaya, dan Action digunakan admin untuk melihat lebih detail informasi permohonan penggantian biaya dan menyetujui permohonan. Halaman Attendance "Full Time" sebagaiamana Gambar 24.

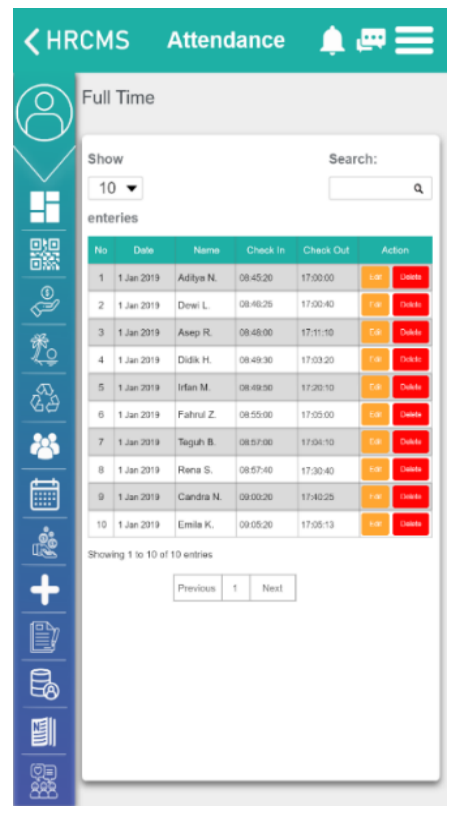

Gambar 24. Tampilan Halaman Attendance “Full Time"

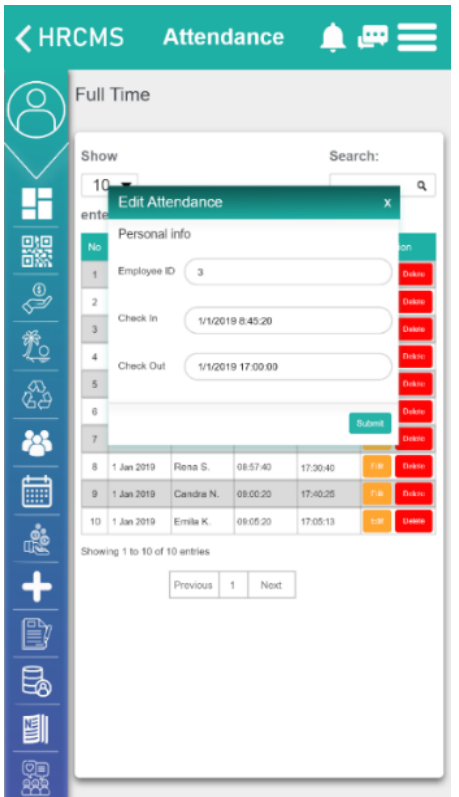

Gambar 25. Tampilan Halaman Edit Attendance Ketika Memilih Edit

Pada Gambar 24 menunjukkan tampilan ketika user memilih fitur Attendance bagian "Full Time". Apabila user memilih fitur tersebut maka dapat melihat daftar - daftar nama pegawai yang bekerja waktu penuh dan kehadiran pegawai. Date digunakan sebagai waktu yang tertera pada kalender. Check In digunakan sebagai waktu ketika pegawai tersebut sudah dating keperusahaan dan 
melakukan absensi. Check Out digunakan sebagai waktu ketika pegawai tersebut akan pulang dan melakukan absensi. Action Edit digunakan admin sebagai perubahan data absensi pegawai dan Action Delete digunakan admin untuk menghapus data absensi pegawai tersebut.

Pada Gambar 25 menunjukkan tampilan ketika admin memilih fitur Edit. Apabila admin memilih fitur tersebut maka akan muncul informasi detail pegawai saat melakukan absensi dan admin dapat mengubah data Check In dan Check Out pegawai tersebut. Halaman Attendance "Part Time" sebagaimana Gambar 26.

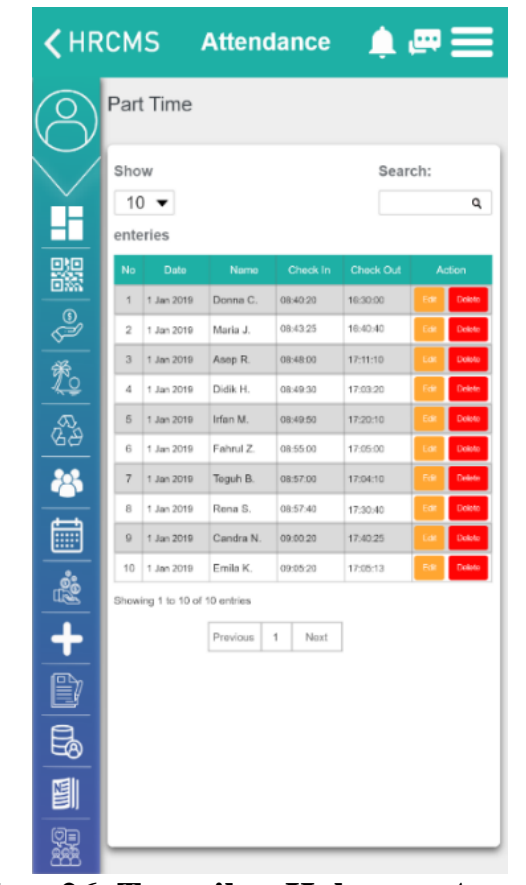

Gambar 26. Tampilan Halaman Attendance "Part Time"

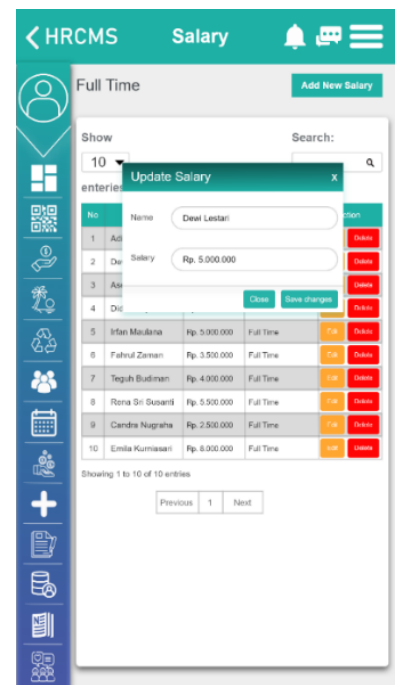

Gambar 28. Tampilan Halaman Update
Salary Ketika Memilih Edit

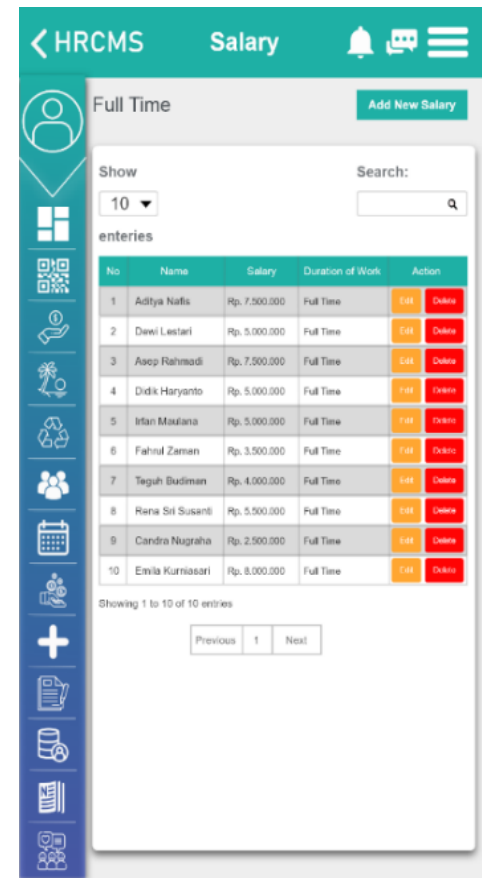

Gambar 27. Tampilan Halaman Salary “Full

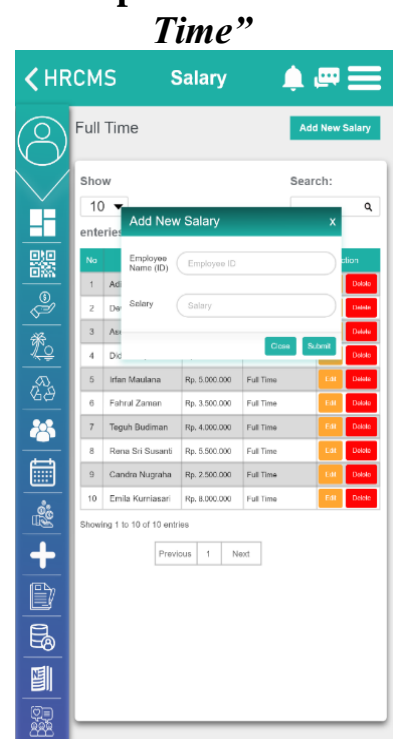

Gambar 29. Tampilan Halaman Add New Salary

Gambar 26 menunjukkan tampilan ketika user memilih fitur Attendance bagian "Part Time". Apabila user memilih fitur tersebut maka dapat melihat daftar - daftar nama pegawai yang bekerja paruh waktu dan kehadiran pegawai. Date digunakan sebagai waktu yang tertera pada kalender. Check In digunakan sebagai waktu ketika pegawai tersebut sudah dating keperusahaan dan melakukan absensi. Check Out digunakan sebagai waktu ketika pegawai tersebut akan pulang dan melakukan 
absensi. Action Edit digunakan admin sebagai perubahan data absensi pegawai dan Action Delete digunakan admin untuk menghapus data absensi pegawai tersebut.

Halaman Salary "Full Time" pada Gambar 27 menunjukkan tampilan ketika user memilih fitur Salary bagian "Full Time". Apabila user memilih fitur tersebut maka dapat melihat daftar - daftar nama pegawai yang bekerja penuh waktu. Salary digunakan untuk melihat gaji pegawai yang sudah ditambahkan. Duration of Work digunakan untuk melihat pegawai yang bekerja secara penuh. Action Edit digunakan admin sebagai perubahan data gaji pegawai dan Action Delete digunakan admin untuk menghapus data pegawai tersebut. Pada Gambar 28 menunjukkan tampilan ketika admin memilih fitur Edit. Apabila admin memilih fitur tersebut maka akan muncul informasi detail nama pegawai dan jumlah gaji karyawan. Gambar 29 menunjukkan tampilan ketika admin memilih fitur Add New Salary. Apabila admin memilih fitur tersebut maka akan muncul Employee Name dan Salary yang dapat diisi. Halaman Salary "Part Time" sebagaimana Gambar 30.

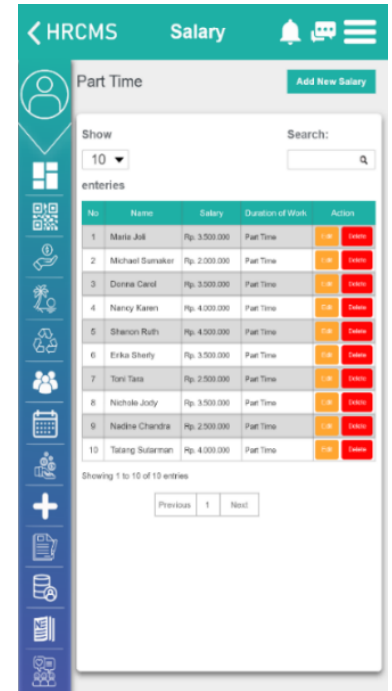

Gambar 30. Tampilan Halaman Salary "Part Time”

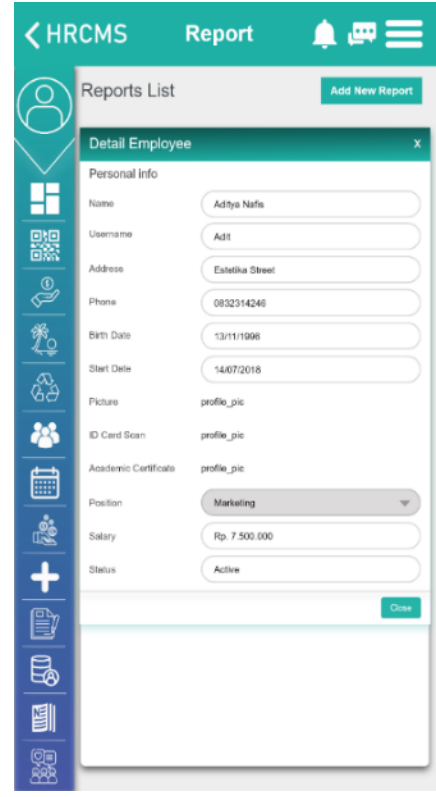

Gambar 32. Tampilan Halaman Detail Employee Ketika Memilih View Detail

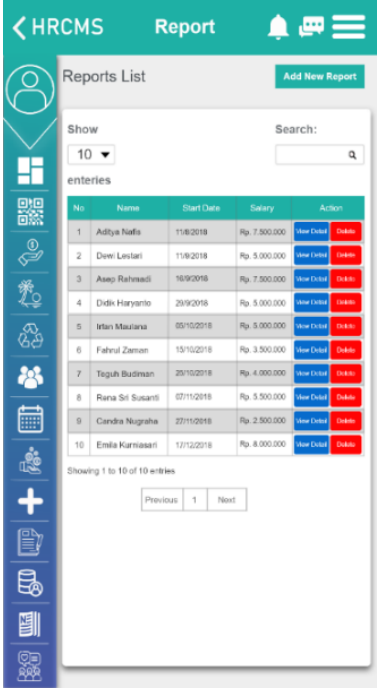

Gambar 31. Tampilan Halaman Report

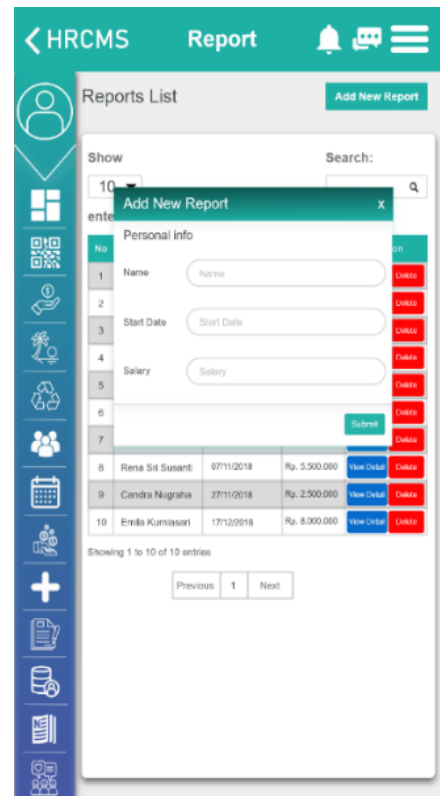

Gambar 33. Tampilan Halaman Add New Report

Gambar 30 menunjukkan tampilan ketika user memilih fitur Salary bagian "Part Time”. Apabila user memilih fitur tersebut maka dapat melihat daftar - daftar nama pegawai yang bekerja paruh waktu. Halaman Report Gambar 31 menunjukkan tampilan ketika user memilih fitur Report. Apabila 
user memilih fitur tersebut maka dapat melihat daftar - daftar nama pegawai yang dilaporkan. Start Date digunakan untuk melihat waktu ketika pegawai di laporkan. Salary digunakan untuk melihat gaji pegawai yang dilaporkan. View Detail digunakan sebagai melihat informasi secara detail pegawai yang dilaporkan dan Action Delete digunakan admin untuk menghapus data pegawai tersebut.

Pada Gambar 32 menunjukkan tampilan ketika admin memilih fitur View Detail. Apabila admin memilih fitur tersebut maka akan muncul informasi detail nama pegawai yang dilaporkan. Gambar 33 menunjukkan tampilan ketika admin memilih fitur Add New Report. Apabila admin memilih fitur tersebut maka akan muncul Name, Start Date, dan Salary yang dapat diisi. Halaman Employee sebagaimana Gambar 34.

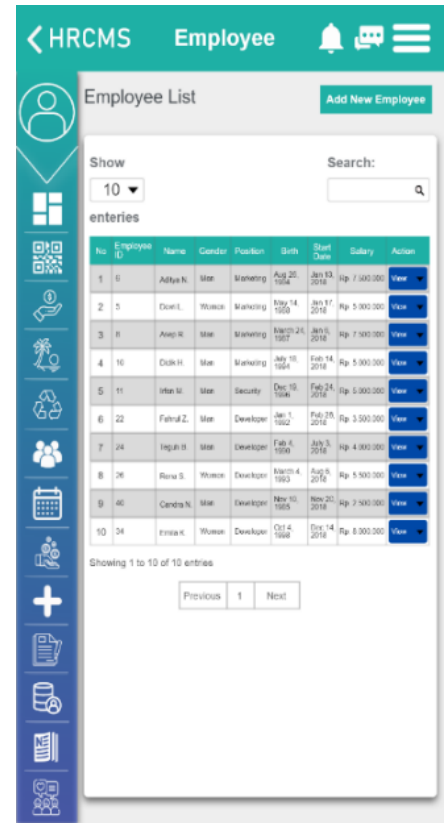

Gambar 34. Tampilan Halaman Employee

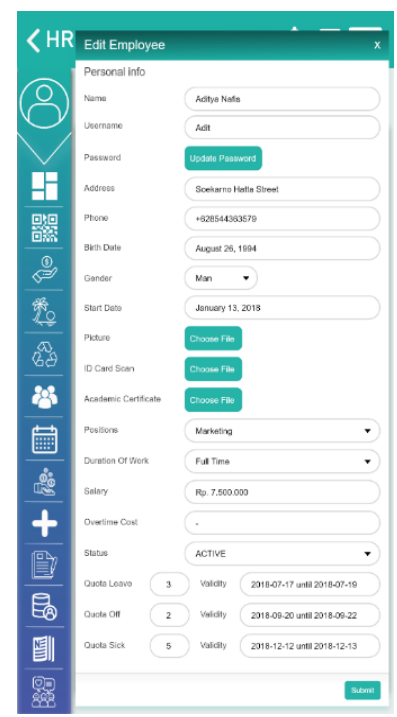

Gambar 36. Tampilan Halaman Edit Employee Ketika Memilih Edit

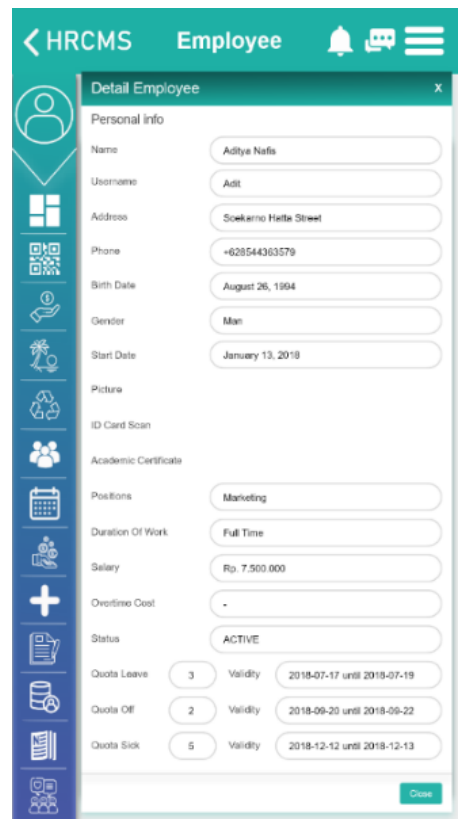

Gambar 35. Tampilan Halaman Detail Employee Ketika Memilih View

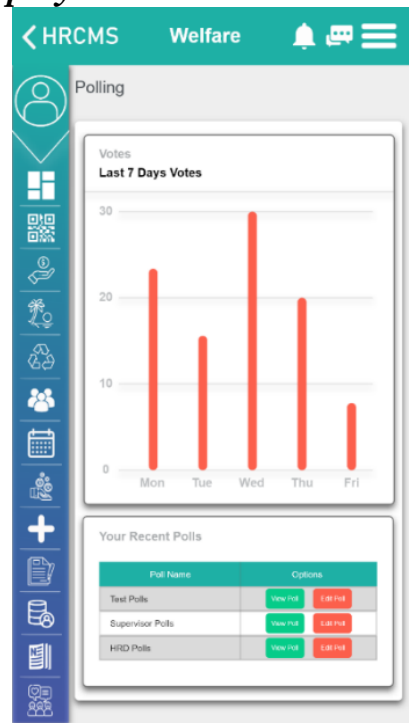

Gambar 37. Tampilan Halaman Welfare "Polling"

Pada Gambar 34 menunjukkan tampilan ketika user memilih fitur Employee. Apabila user memilih fitur tersebut maka dapat melihat daftar - daftar nama pegawai. Employee ID digunakan untuk mengetahui nomor identitas pegawai. Gender digunakan untuk mengetahui jenis kelamin pegawai. Position digunakan untuk mengetahui posisi pegawai dalam perusahaan. Birth digunakan untuk mengetahui tanggal lahir pegawai. Start Date digunakan untuk mengetahui pertama kali 
pegawai bekerja dalam perusahaan. Salary digunakan untuk mengetahui gaji yang diterima pegawai dan Action digunakan admin untuk bertindak. Gambar 35 menunjukkan tampilan ketika admin memilih fitur View. Apabila admin memilih fitur tersebut maka akan muncul informasi detail pegawai yang dipilih. Gambar 36 menunjukkan tampilan ketika admin memilih fitur Edit. Apabila admin memilih fitur tersebut maka akan muncul informasi detail pegawai dan admin dapat merubah data pegawai yang dipilih.

Halaman Welfare "Polling" Gambar 37 menunjukkan tampilan ketika user memilih fitur Welfare "Polling". Apabila user memilih fitur tersebut maka dapat melihat hasil Votes yang telah dilakukan selama 7 hari terakhir dan dapat melihat daftar Polls yang sudah pernah dilakukan. View Poll digunakan untuk melihat detail polling yang dilakukan dan Edit Poll digunakan untuk mengubah data polling yang dilakukan. Halaman Welfare "Survey" sebagaimana Gambar 38.

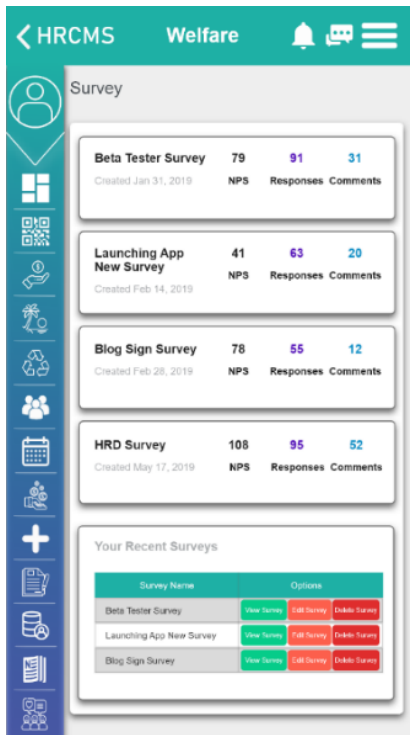

Gambar 38. Tampilan Halaman Welfare "Survey"

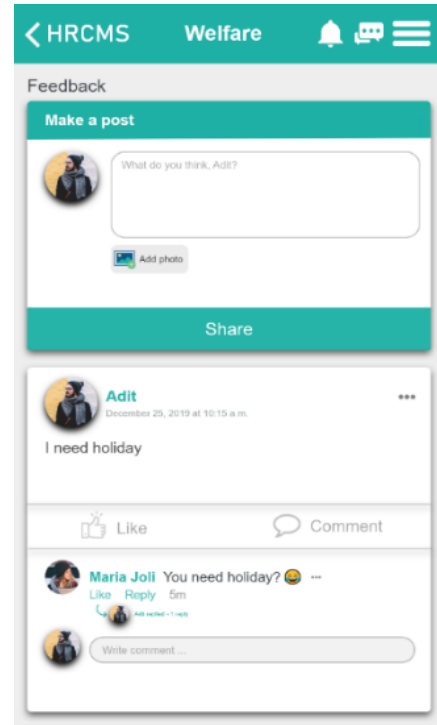

Gambar 39. Tampilan Halaman Welfare "Feedback"

Pada Gambar 38 menunjukkan tampilan ketika user memilih fitur Welfare "Survey". Apabila user memilih fitur tersebut maka dapat melihat hasil Survey yang telah dilakukan dan dapat melihat daftar Surveys yang sudah pernah dilakukan. View Survey digunakan untuk melihat detail survey yang dilakukan. Edit Survey digunakan untuk mengubah data survey yang dilakukan dan Delete Survey digunakan untuk menghapus survey yang dipilih. Pada Gambar 39 menunjukkan halaman Welfare "Feedback". Apabila user memilih fitur tersebut maka dapat melihat status pegawai maupun admin dan dapat membalas maupun menyukai status yang dipilih. Halaman Bonus sebagaimana terlihat pada Gambar 40. 


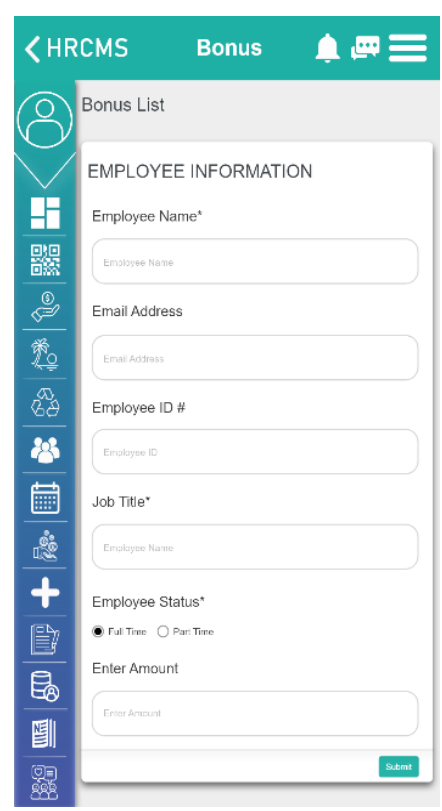

Gambar 40. Tampilan Halaman Bonus

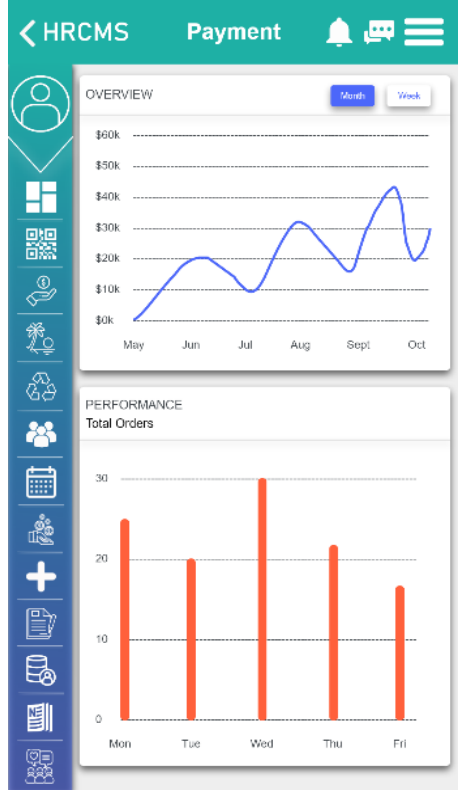

\section{Gambar 41. Tampilan Halaman Payment}

Pada Gambar 40 menunjukkan tampilan ketika user memilih fitur Bonus. Apabila user memilih fitur tersebut maka dapat memberikan upah tambahan diluar gaji yang dibayarkan kepada pegawai. Pada Gambar 41 menunjukkan tampilan ketika user memilih fitur Payment. Apabila user memilih fitur tersebut maka dapat melihat kegiatan keuangan dalam perusahaan tersebut, baik pada pembayaran keluar maupun dalam perusahaan. Halaman News sebagaimana Gambar 42.

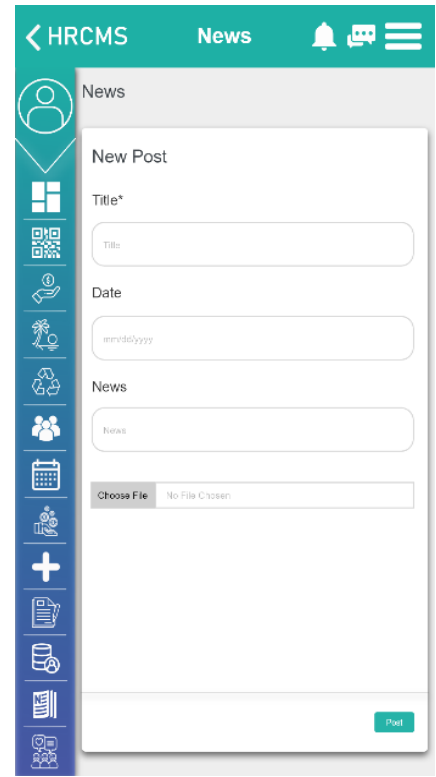

Gambar 42. Tampilan Halaman News
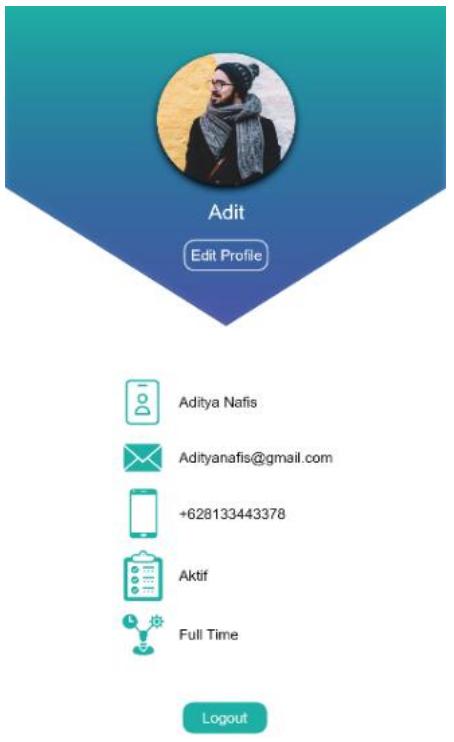

Gambar 43. Tampilan Halaman Profile 


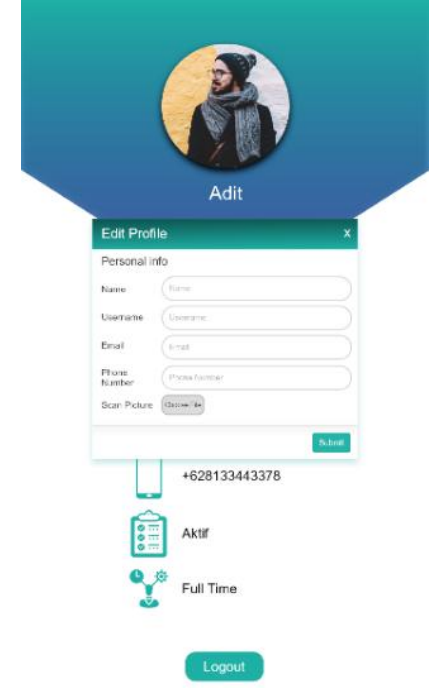

Gambar 44. Tampilan Halaman Pop Up Edit Profile

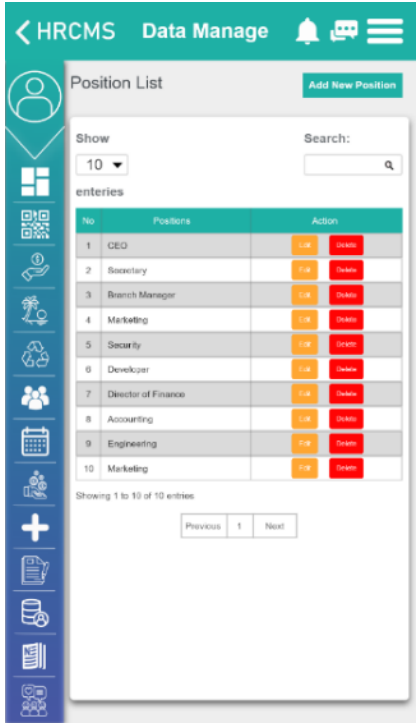

Gambar 45. Tampilan Halaman Data Manage "Position List"

Pada Gambar 42 menunjukkan tampilan ketika user memilih fitur Payment. Apabila user memilih fitur tersebut maka dapat membuat berita atau pengumuman di perusahan agar dapatdilihat oleh seluruh karyawan di dalam perusahaan yang akan tampil pada halaman dashboard atau halaman utama dalam aplikasi. Gambar 43 menunjukkan tampilan ketika user memilih fitur Profile. Apabila user memilih fitur tersebut makadapat melihat data akun yang sudah diisi saat membuat akun. Pada fitur ini user dapat melakukan Logout. Gambar 44 menunjukkan tampilan ketika user memilih fitur Edit Profile maka akan muncul pop up apabila user ingin merubah data. Halaman Data Manage "Position List" sebagaimana Gambar 45. Apabila user memilih fitur tersebut maka dapat melihat daftar posisi pekerjaan yang dibutuhkan oleh perusahaan. Add New Position digunakan untuk menambahkan posisi pekerjaan yang dibutuhkan. Edit digunakan untuk merubah nama posisi pekerjaan yang sudah ada. Delete digunakan untuk menghapus data nama posisi yang ada dalam daftar. Tampilan halaman Add New Position sebagaimana Gambar 46.

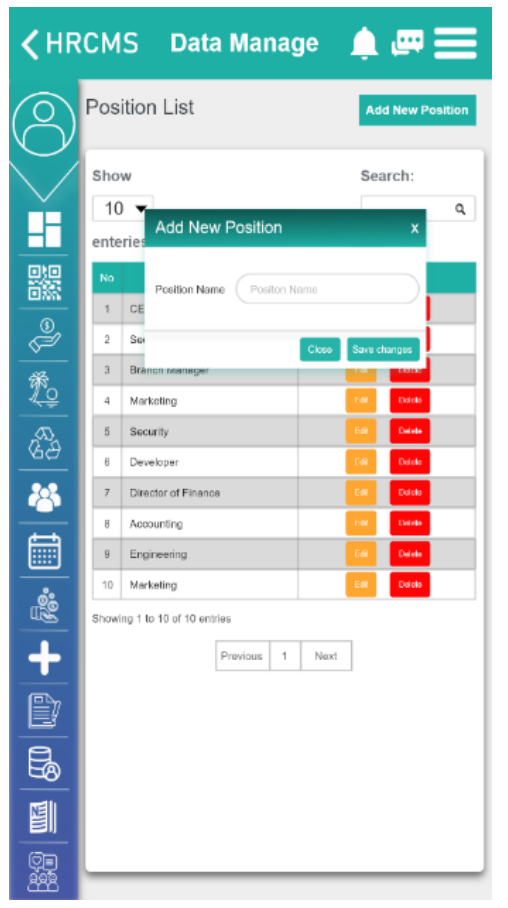

Gambar 46. Tampilan Halaman Add New Position

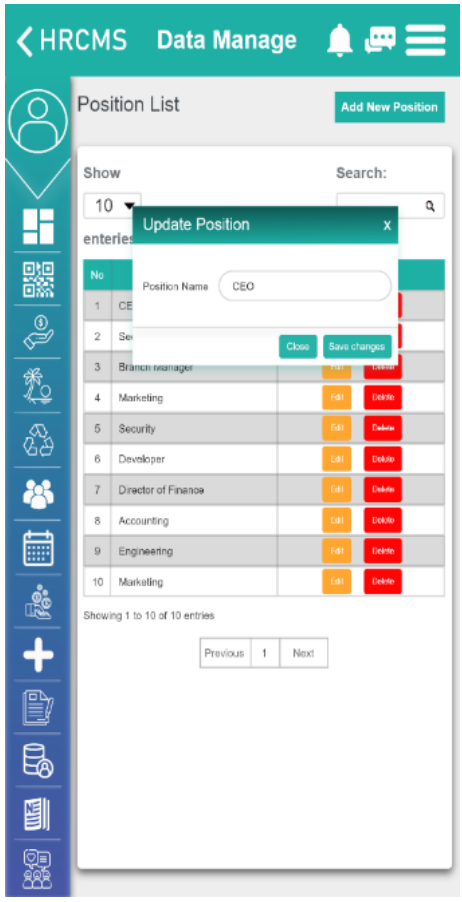

Gambar 47. Tampilan Halaman Update Position 
Pada Gambar 46 menunjukkan tampilan ketika admin memilih fitur Add New Position. Apabila admin memilih fitur tersebut maka akan muncul Position Name yang akan ditambahkan. Gambar 47 menunjukkan tampilan ketik aadmin memilih fitur Edit. Apabila admin memilih fitur tersebut maka akan muncul halaman Update Position yang dimana berisikan Position Name yang dapat dirubah. Halaman Data Manage "Allowance List” sebagaimana Gambar 48.

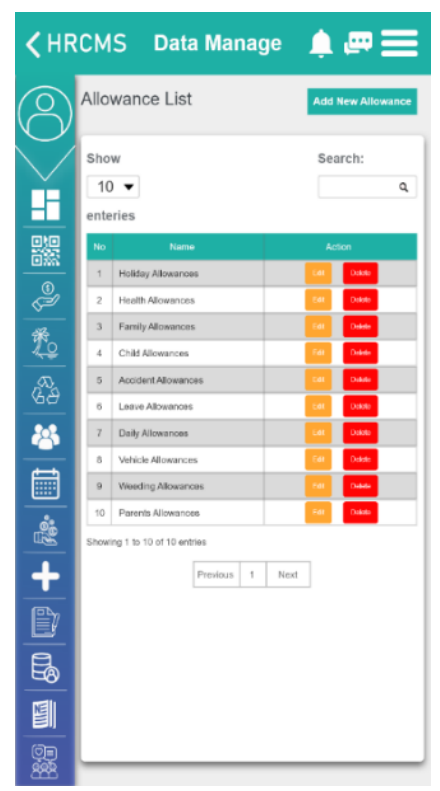

Gambar 48. Tampilan Halaman Data Manage "Allowance List"

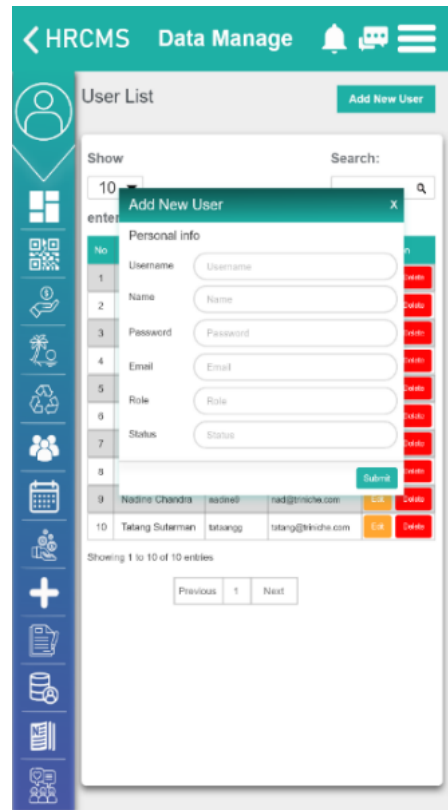

Gambar 50. Tampilan Halaman Add New User

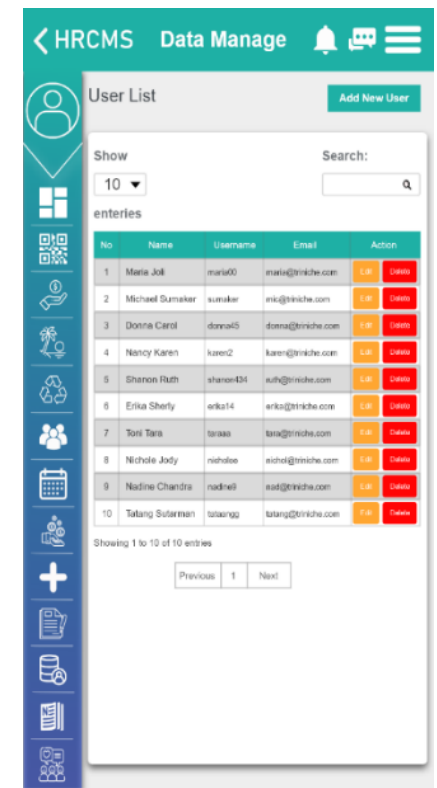

Gambar 49. Tampilan Halaman Data Manage "User List"

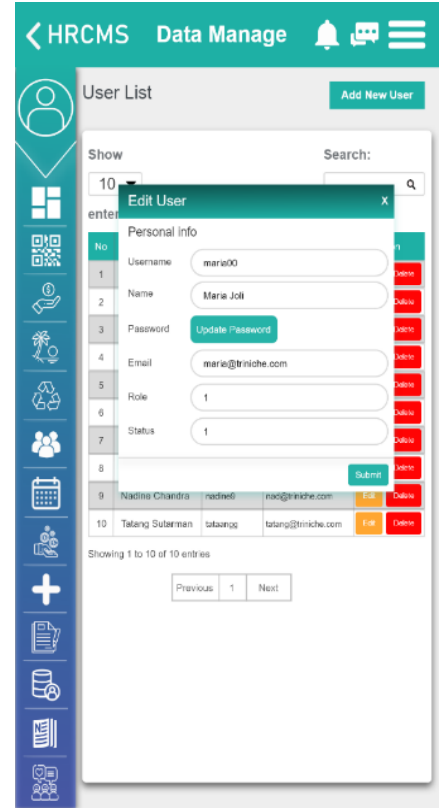

Gambar 51. Tampilan Halaman Edit User

Gambar 48. menunjukkan tampilan ketika user memilih fitur Data Manage "Allowance List". Apabila user memilih fitur tersebut maka dapat melihat daftar tunjangan yang didapatkan pegawai dari perusahaan. Add New Allowance digunakan untuk menambahkan tunjangan baru. Edit digunakan untuk merubah nama tunjangan yang sudah ada. Delete digunakan untuk menghapus data nama tunjangan yang ada dalam daftar.

Pada Gambar 49 menunjukkan tampilan ketika user memilih fitur Data Manage "User List". Apabila user memilih fitur tersebut maka dapat melihat daftar data admin yang sudah terdaftar. Username digunakan untuk nama singkat yang diinginkan. Email digunakan untuk mengirimkan 
pesan kepada seluruh akun pegawai yang sudah terdaftar. Add New User digunakan untuk menambahkan data admin baru. Edit digunakan untuk merubah data admin yang sudah ada. Delete digunakan untuk menghapus akun admin yang ada dalam daftar. Gambar 50 menunjukkan tampilan ketika admin memilih fitur Add New User. Apabila admin memilih fitur tersebut maka akan muncul informasi yang dapat diisi oleh admin yang ingin ditambahkan. Gambar 51 menunjukkan tampilan ketika admin memilih fitur Edit. Apabila admin memilih fitur tersebut maka akan muncul halaman Edit User yang berisikan data lengkap admin yang dipilih dan admin lainnya dapat merubah data admin.

\section{KESIMPULAN}

Adapun kesimpulan dalam penelitian ini diantaranya, pembangunun user interface aplikasi pemantauan data pegawai menggunakan HRCMS menggambarkan secara jelas mengenai fitur sistem. Pembangunan user interface menggunakan HRCMS membantu dalam pemenuhan kebutuhan pengguna secara detil. User interface pemantauan data pegawai yang dibangun menggunakan HRCMS sebagai pendukung dalam pembangunan aplikasi yang nantinya dapat digunakan sebagai acuan. User Interface yang sederhana berdasarkan prinsip User Interface Design dapat memudahkan para pegawai dalam penggunaan aplikasi seperti melakukan pengajuan cuti dengan mudah.

\section{REFERENSI}

[1] Tri-Niche Inspiring Social Awareness Throught IT. [Online] Available at : https://www.triniche.com/id/tentang-kami/ [Diakses 158 2020].

[2] A. Nurlifa, S. Kusumadewi, dan Kariyam., "Analisis Pengaruh User Interface Terhadap Kemudahan Pengunaan Sistem Pendukung Keputusan Seorang Dokter". Prosiding SNATIF (1). 333-340, 2014.

[3] Y. Adhipratama, T. Sagirani and P. Kartikasari., "Perancangan Antarmuka Pengguna Dengan Metode Lean Ux Pada Website Hello Work Dinas Tenaga Kerja Kabupaten Pasuruan," JSIKA, vol. 7, 2018.

[4] Alomari, H. W., Ramasamy, V., Kiper, J. D., \& Potvin, G. (2020). A User Interface (UI) and User eXperience (UX) evaluation framework for cyberlearning environments. Holiyon. 1-18.

[5] A. A. Pratama, P. Sudarmaningtyas, S. H. E. Wulandari., "User Interface/User Experience Dengan Metode Google Design Sprint Dan A/B Testing Pada Website Startup Qtaaruf," JSIKA Vol. 7, No. 4, 2018

[6] W. Wibawanto and R. Nugrahani., "Desain Antarmuka (User Interface) Pada Game Edukasi," Jurnal Imajinasi, p. 60, 2018.

[7] I. Santosa., Interaksi Manusia dan Komputer, Yogyakarta: Andi, 2004.

[8] A. Mursyidah, I. Aknuranda and H. M. Az-Zahra., "Perancangan Antarmuka Pengguna Sistem Informasi Prosedur Pelayanan Umum Menggunakan Metode Design Thinking (Studi Kasus: Fakultas Ilmu Komputer Universitas Brawijaya)," Jurnal Pengembangan Teknologi Informasi dan Ilmu Komputer, vol. 3, pp. 3931-3938, 2019

[9] R. Layona, dan B. Yulianto,. "Aplikasi pencarian informasi dan lokasi tempat makan pada perangkat mobile berbasis android". Jurnal Teknologi dan Sistem Informasi, 2(2), 9-16, 2016.

[10] F. A. Handiman, dan G.G. Sembada., "Perancangan User Interface Aplikasi Mobile Pasar Kampus". eProceedings of Art \& Design, 2016.

[11] T. Chandra., "Evaluasi User Interface Desain Sistem Informasi Perpustakaan Pada Perguruan Husni Thamrin Medan". Jurnal TIMES, 2015.

[12] B. Shneiderman and C. Plasant, Designing User Interface, United States of America: Pearson Education Inc., 2005.

[13] J. Preece, Y. Rogers dan H. Sharp, Interaction Design: Beyond Human-Computer Interaction, Chichester, UK: John Wiley \& Sons, 2015.

[14] The U.S. Department of Health and Human Services; The U.S. General Services Administration, Research-Based Web Design \& Usability Guidelines, Washington DC: U.S. Government Printing Office, 2006.

[15] A. Assila, K. M. d. Oliveira dan H. Ezzedine, "Standardized Usability Questionnaires: Features and Quality Focus," Electronic Journal of Computer Science and Information Technology, vol. 6, 
no. 1 , pp. 15-31, 2016.

[16] D. Chasanidou, A. A. Gasparini and E. Lee, "Design Thinking Methods and Tools for Innovation," in HCI International, Los Angeles, 2015.

[17] G. Pandusarani, A. H. Brata dan E. M. A. Jonemaro, "Analisis User Experience Pada Game CS:GO dengan Menggunakan Metode Cognitive Walkthrough dan Metode Heuristic Evaluation," Jurnal Pengembangan Teknologi Informasi dan Ilmu Komputer, vol. 2, pp. 940950, 2018

[18] Karim, N. A., Shukur, Z., \& AL-banna AbedElkarim M. (2020). UIPA: User authentication method based on user interface preferences for account recovery. Journal of Information Security and Applications. 52, pp 1-14. 